\title{
虚弱子牛に認められた腎臓形成異常
}

高畑幸子 ${ }^{1)}$ 千葉正寛 ${ }^{3)}$ 沼津敬治 ${ }^{2)}$ 渡辺昭夫 ${ }^{3)}$ 一條俊浩 ${ }^{1)}$

蓬田信一 ${ }^{1)}$ 八島 正 $^{11}$ 松田敬一 ${ }^{2)}$ 川名晶子 ${ }^{21}$

${ }^{1)}$ NOSAI宮城県北家畜診療センター、 ${ }^{2)} \mathrm{NOSAI}$ 宮城中央家畜診療センター、

${ }^{3)}$ NOSAI宮城県南家畜診療センター

\section{Renal Malformation in the Calves with Weak Calf Syndrome}

S. Takahata ${ }^{1)}$, M. Chiba ${ }^{3)}$, K. Numatsu ${ }^{2)}$, A. Watanabe ${ }^{3)}$, T. Ichijo ${ }^{1)}$, S. Yomogida ${ }^{1)}$, T. Yashima ${ }^{1)}$, K. Matsuda ${ }^{2)}$, A. Kawana ${ }^{2)}$

${ }^{1)}$ Miyagi Prefectural Federated Agricultural Murual Aid Association (PFAMAA), Kenpoku Clinical Center, ${ }^{2}$ PFAMAA, Central Clinical Center,

${ }^{3}$ PFAMAA, Kennan Clinical Center

\begin{abstract}
要 約 平成 14 年 6 月〜8月までに管内黒毛和牛繁殖農家に飼育されていた子牛で子牛虚弱症候群と 診断された 3 症例（症例 $1 、 13$ 日齢、体重約 $12 \mathrm{~kg}$ 、雄。症例 $2 、 51$ 日齡、体重約 $30 \mathrm{~kg}$ 、雄。症例 $3 、 2$ 日齢、体重約 $10 \mathrm{~kg}$ 、雄。）について、臨床症状、血液生化学検查、超音波断層検查、病理組織検査㧍上 び家系調查を行った。その結果、臨床症状については全症例において元気沈焚、哺乳欲不振、発育不良 および皮毛粗㴊が認められた。血液生化学検査では全症例においてクレアチニン（Cre）の高值が認め られ、症例 1 抢よび 2 において血中尿素窒素（BUN）の高值が認められた。超音波断層検査では症例

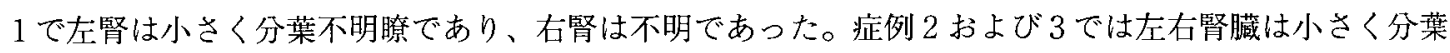
が不明瞭であった。剖検時の腎臓の肉眼所見でも、腎臓の表面は退色し分葉が不明瞭であった。組織学 的には、全症例において未熟小型腎単位や原始集合菅が認められ、疫痕化組織や炎症性反応は全く認め られなかった。家系調査では全症例扔いて茂金系種雄牛 A を頂点とした交配環境にあった。腎臓の形成 異常は様々な要因によって引き起こされるが、全症例に扔いて種雄牛 $\mathrm{A} か ゙$ 深く関与しており、遺伝的疾 患である可能性が推察された。また、血液検査で腎臓の異常が疑われる場合に超音波断層検查を行うこ とは、診断の一助になるものと考えられた。

一キーワード：黑毛和種、子牛虚弱症、腎不全、腎形成異常
\end{abstract}

-家畜臨床誌２7(1):1-6, 2004

ABSTRACT Three newborn Japanese Black cattle which presented weak calf syndrome from June to August 2002 in breeding farms within the jurisdiction were examined for clinical symptoms, blood chemistry, ultrasound tomography, histopathology and family history (Case 1: 13-dayold male with $12 \mathrm{~kg}$ bodyweight, Case 2: 51-day-old male; $30 \mathrm{~kg}$, Case 3: 2-day-old male; $10 \mathrm{~kg}$ ). Clinical symptoms included loss of vigor, inability to nurse, poor growth and rough haircoat in all calves. Blood chemistry showed elevated creatinine in all three and elevated BUN in Cases 1 and 
2. Ultrasound tomographic examinations revealed that in Case 1 the left kidney was underdeveloped and unlobed, and the right kidney was not found. In Cases 2 and 3, both kidneys were small and unlobed. Gross examination at the autopsy also showed unlobed kidneys with discolored surfaces. Histopathologically, underdeveloped small nephrons and primitive collecting tubules were found in all cases, while there was no sign of scarring or inflammation. Their family trees were all tracked back to a Shigekane breeding bull A. This indicated that abnormal kidneys in these cases were hereditary, although kidney malformation may be caused by various factors. Further, our study suggested that ultrasonography may help diagnosis of kidney malformation when abnormalities in the renal function are indicated by blood chemistry.

Key Words: Japanese Black cattle, weak calf syndrome, renal failure, renal malformation Jpn. J. Vet. Cinics 27(1):1-6, 2004

\section{緒 言}

和牛において子牛の周産期死亡率は高く、生産性を左 右する大きな要因のひとつとなっている。子牛の周産期 死亡は生後 1 週間以内に集中して起こるとされているが、 死亡原因を特定できない例が多く〔7〕、それらの大半 は新生子の虚弱によるものと推察されている。新生子の 虚弱の発症要因としては難産による低酸素血症〔3〕を はじめ、虚弱子牛の大半に胎子期の造血機能障害〔 4 〕 および胎子一胎盤機能の低下による母体内発育遅延が認 められたという報告〔6〕もある。また、脂肪交雑が重 視された育種改良の結果、近親交配による負の産物とし て遺伝性疾患の発生も多くみられるようになった。宮城 県北部では腎臓の著しい低形成を伴った先天性下顎短小 症の発生が多く認められており、遺伝性疾患である可能 性が非常に高いと推察されている。今回我々は、腎臟の 形成異常を呈した虚弱子牛に遭遇したのでその概要を報 告する。

\section{材料および方法}

調查期間は平成14年 6 月 8 月までの 3 ヶ月間で、調 查対象牛は管内黒毛和種繁殖農家に飼育されていた子牛 3 頭である。症例 1 は 13 日齢、体重約 $12 \mathrm{~kg}$ 、雄で、出生 した翌日に元気なく哺乳もしないとの禀告で診察した。 症例 2 は51日齢、体重約 $30 \mathrm{~kg}$ 、雄で、発育不良との稟告 で診察した。症例 3 は 2 日齢、体重約 $10 \mathrm{~kg}$ 、雄で、出生 した日に元気が全くなく哺乳もしないとの禀告で診察した。 すべての症例について臨床症状を調査して採血を実施 した。血液生化学検查は、自動分析装置（スポットケム、 京都第一科学、京都）を用いて検査した。また、超音波 診断装置（SSD-500、アロカ株式会社、東京）を用いて、 腎臓の超音波断層検查を行った。左右けん部の最後肋骨
にリニア形探触子の頭側部を体軸に平行になるようにあ て、腎臓の断層画像を撮影した。症例 1 お よび 2 は予後 不良のため放血殺にて安楽死後、剖検に供した。症例 3 は補液などの治療を実施したが翌日死亡したため、死亡 後剖検に供した。病理組織学的検査は、腎臓を $10 \%$ ホル マリン液にて固定後、薄切しへマトキシリン・エオジン （HE）染色抒よびPAS染色標本を作製し精査した。家系 調査は、 3 代祖まで行った。

\section{結 果}

\section{〈症例 1 〉(図 1$)$}

臨床症状

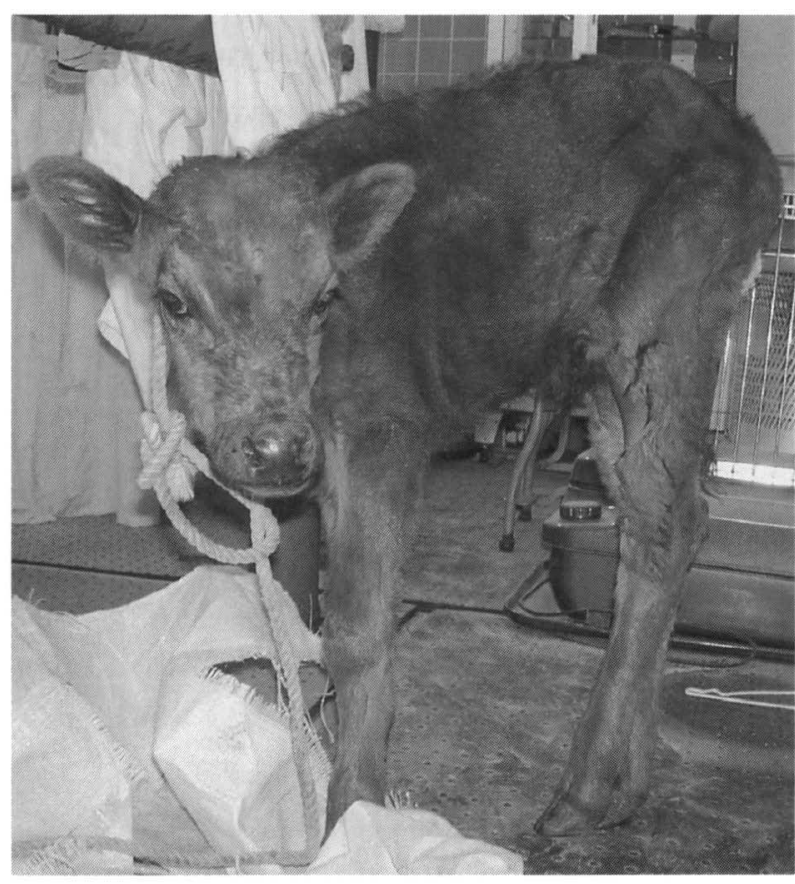

図 1 症例 1 の子牛

13 日齢、体重約 $12 \mathrm{~kg}$ 、雄。活力がなく、 歩様蹌踉、被毛粗剛、脱毛が目立った。 
リンゲル液や抗生物質、強肝剂などの投与により自力 で哺乳するようになったが、活力の回復はみられず、常に うずくまり、歩様蹌踉、被毛粗剛、脱毛が目立った。排便、 排尿は認められた。以上の所見より子牛虚弱症候群と診 断した。

血液生化学検查（表 1 )

6 病日ではHt值は低く、BUNおよびCreは著しく高値 を示していた。11病日にはAlbが低下し、BUN、Creは さらに上昇していたことから、腎機能不全が疑われた。

表 1 血液生化学検査（症例 1 )

\begin{tabular}{llcc}
\hline & & 6 病日 & 11 病日 \\
\hline Ht & $(\%)$ & 24 & 24 \\
\hline AST & $(\mathrm{IU} / \mathrm{l})$ & 24.0 & 43.0 \\
\hline $\mathrm{GGT}$ & $(\mathrm{IU} / \mathrm{l})$ & 258.0 & 145.0 \\
\hline BUN $(\mathrm{mg} / \mathrm{dl})$ & 56.0 & 80.0 \\
\hline Cre $\quad(\mathrm{mg} / \mathrm{dl})$ & 5.6 & 6.7 \\
\hline $\mathrm{TP}$ & $(\mathrm{g} / \mathrm{dl})$ & 7.3 & 7.8 \\
\hline $\mathrm{Alb}$ & $(\mathrm{g} / \mathrm{dl})$ & 3.0 & 2.8 \\
\hline
\end{tabular}

超音波断層検査（図 2 )

症例 1 には第12病日に超音波断層検査を実施した。対 照牛として 4 日齢で生化学検査に異常の認められない黒 毛和種牛を用いた。対照牛では分葉した腎蔵が確認され たが、症例では分葉構造はみられず、扁平で小さい腎蔵 が認められた。右腎は不明であった。

病理学的検査

左腎は大きさ $5.0 \times 3.4 \mathrm{~cm}$ 、重さ $16.5 \mathrm{~g}$ 、表面は退色し 分葉不明瞭で、割面では皮髄境界不明瞭であった（図 3 )。 右腎は血管走行より探索したが、血管の走行は一部は筋 膜に付着し、分岐した血管は表面が白色のリンパ節様組 織へつながっており、右腎は確認されなかった。リンパ 節様組織は大きさ $0.9 \times 0.5 \mathrm{~cm}$ 、重さ $0.4 \mathrm{~g}$ であった。病理
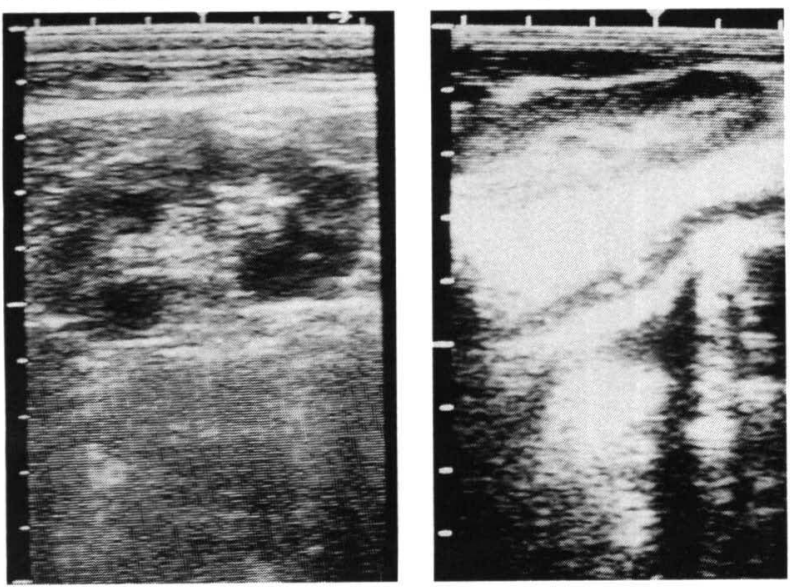

図 2 超音波断層検査（症例 1 ） 対照牛



図 3 左腎およびリンパ節様組織（症例 1 )

左腎は大きさ $5.0 \times 3.4 \mathrm{~cm}$ 、重さ $16.5 \mathrm{~g}$ 、表面は退色し分 葉不明瞭であった。右腎は確認されなかった。

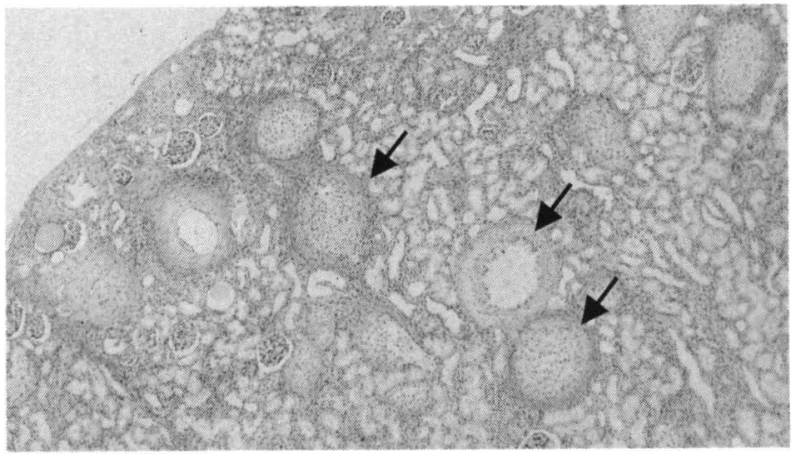

図 4 症例 1 の腎臟（低倍）

原始集合管 (矢印) が左腎の皮質領域に多数認められた。

組織学的には、左腎の腎実質は髄質部領域が狭く、個々 の腎単位は正常のものより小さく、皮質領域に淡明で腫 大した上皮細胞で内張りされ重層化した原始集合管が多 数認められた（図 4 、図 5 )。瘕痕化組織や炎症性反応 は全く認められなかった。また、右側のリンパ節様組織 は組織学的にリンパ節であることが確認された。

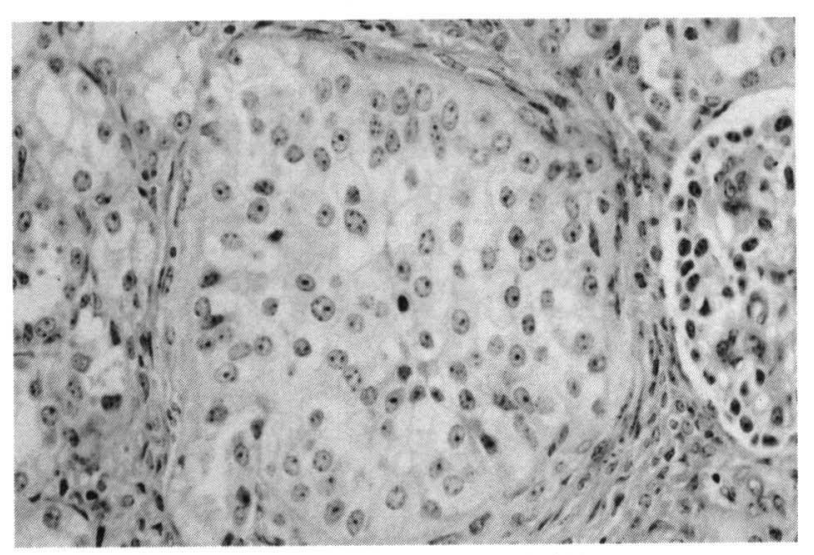

図 5 症例 1 の腎臟 (高倍)

原始集合管部分の拡大図。淡明で腫大した上皮細胞で内 張りされ重層化している。 
〈症例 2 〉(図 6)

\section{臨床症状}

51日齢で体重約 $30 \mathrm{~kg}$ であり、発育不良であった。また、 活力、食欲不振で、被毛粗剛であった。排便、排尿は認 められた。この症例は新生子期に、活力がなく哺乳欲不 振で子牛虚弱症候群と診断され治療をした病歴があった。

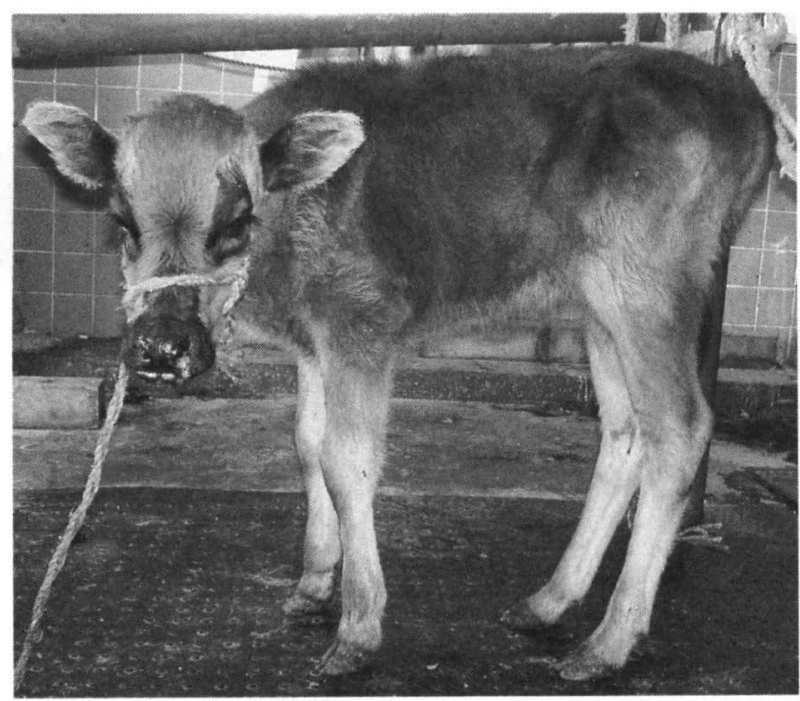

図 6 症例 2 の子牛

51 日齢、体重約 $30 \mathrm{~kg}$ 、雄。発良不良で活力、食欲不振、 被毛粗剛であった。

血液生化学検查 (表 2 )

1 病日、 7 病日ともBUNおよびCreが高值を示してい た。以上の所見より慢性腎不全と診断した。

超音波断層検査（図 7 )

症例 2 には第 7 病日に超音波断層検査を実施した。対 照牛として60日齢で生化学検査に異常の認められない黒 毛和種牛を用いた。対照牛では分葉した腎蔵が確認され たが、症例では左右とも分葉不明瞭で小さい腎臓が認め られた。

表 2 血液生化学検査（症例 2)

\begin{tabular}{llcc}
\hline & & 1 病日 & 7 病日 \\
\hline Ht $(\%)$ & 34 & 34 \\
\hline AST $(\mathrm{IU} / \mathrm{l})$ & 54.0 & 54.3 \\
\hline $\mathrm{GGT}(\mathrm{IU} / \mathrm{l})$ & 40.0 & 57.0 \\
\hline $\mathrm{BUN}(\mathrm{mg} / \mathrm{dl})$ & 44.0 & 46.0 \\
\hline $\mathrm{Cre}(\mathrm{mg} / \mathrm{dl})$ & 3.0 & 2.3 \\
\hline $\mathrm{TP}(\mathrm{g} / \mathrm{dl})$ & 5.2 & 5.4 \\
\hline $\mathrm{Alb}(\mathrm{g} / \mathrm{dl})$ & 2.9 & 2.9 \\
\hline
\end{tabular}
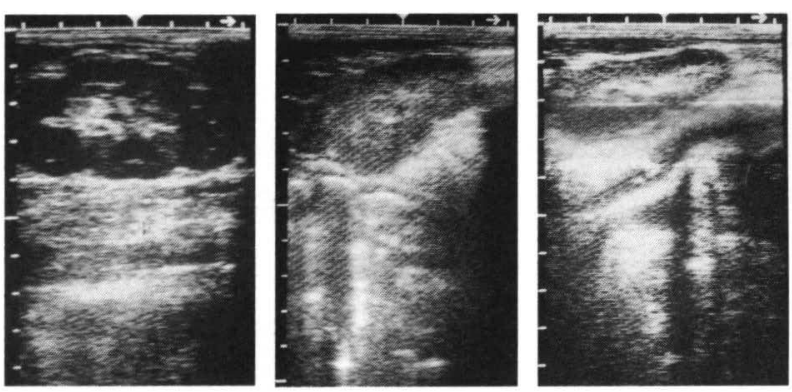

図 7 超音波断層検査（症例 2)

対照牛左腎腎

\section{病理学的検査}

左腎は大きさ $4.5 \times 2.7 \mathrm{~cm}$ 、重さ $15.3 \mathrm{~g}$ 、右腎は大きさ $5.0 \times 2.5 \mathrm{~cm}$ 、重さ $15.1 \mathrm{~g}$ で、どちらも表面は退色し分葉 不明瞭で（図 8 ）、割面では皮髄境界不明瞭であった。 組織学的には、特に髄質の発達が悪く、皮質中に䯣質が 混在しており、腎杯を形成していない領域も認められた。 未熟小型腎単位が索状に残存している領域もみられ、尿 細管上皮が重層化して管腔内を埋める像も認められた (図9)。

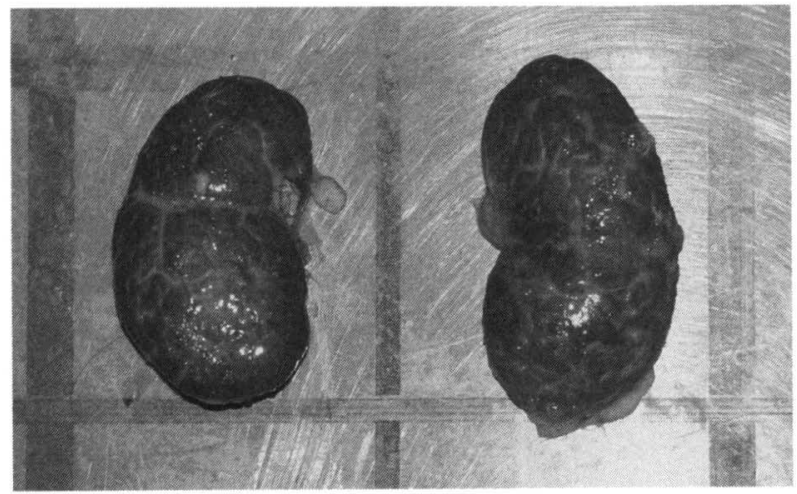

図 8 左腎および右腎（症例 2）

左腎は大きさ $4.5 \times 2.7 \mathrm{~cm}$ 、重さ $15.3 \mathrm{~g}$ 、右腎は大きさ 5.0 $\times 2.5 \mathrm{~cm}$ 、重さ $15.1 \mathrm{~g}$ で、表面は退色し、分葉不明瞭であっ た。



図 9 症例 2 の腎臓（低倍）

矢印: 尿細管上皮細胞が重層化し管腔内を埋めている。 
〈症例 3 〉(図10)

\section{臨床症状}

妊娠期間は283日であったが、出生時体重は約 $10 \mathrm{~kg}$ で あり、母体内発育遅延が認められた。出生後起立不能で 横臥し、活力、哺乳欲は全く無く、補液などの治療を行っ たが、翌日死亡した。以上の所見より子牛虚弱症候群と 診断した。

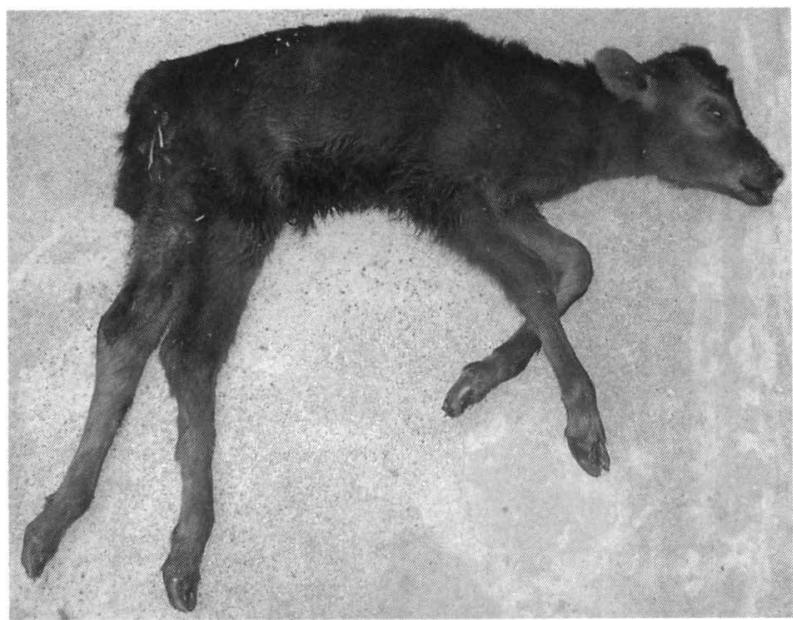

図10 症例 3 の子牛

2 日齢、体重約 $10 \mathrm{~kg}$ 、雄。出生後より、活力、哺乳欲は 全く無く、死亡した。

血液生化学検查（表 3 ）

Creが著しく高値を示していた。

表 3 血液生化学検査（症例 3 )

\begin{tabular}{llc}
\hline & & 1 病日 \\
\hline $\mathrm{Ht}$ & $(\%)$ & 27 \\
\hline AST $(\mathrm{IU} / \mathrm{l})$ & 113.0 \\
\hline $\mathrm{GGT}(\mathrm{IU} / \mathrm{l})$ & - \\
\hline BUN $(\mathrm{mg} / \mathrm{dl})$ & 17.0 \\
\hline Cre $(\mathrm{mg} / \mathrm{dl})$ & 7.2 \\
\hline TP $(\mathrm{g} / \mathrm{dl})$ & 4.2 \\
\hline Alb $(\mathrm{g} / \mathrm{dl})$ & 2.1 \\
\hline
\end{tabular}

超音波断層検查（図11）

症例 3 には第 1 病日に超音波断層検査を実施した。対 照牛として 4 日齢で、生化学検査に異常の認められない 黒毛和種牛を用いた。対照牛では分葉した腎臓が確認さ れたが、症例は左右とも分葉不明瞭で小さい腎臓が認め られた。


図11 超音波断層検査（症例 3） 対照牛

左腎

右腎

\section{病理学的検査}

左腎は大きさ $3.6 \times 1.7 \mathrm{~cm}$ 、重さ $7.8 \mathrm{~g}$ 、右腎は大きさ 3.2 $\times 2.0 \mathrm{~cm}$ 、重さ $6.3 \mathrm{~g}$ で左右腎臓とも表面は退色し、分葉 不明瞭で針頭大の凹部がみられた（図12）。また、膀胱 内に無色透明の尿が貯留していた。割面では左右とも皮 髄境界不明瞭で、左腎の皮質には暗赤色部が認められた。 病理組織学的には、髄質の発達が悪く、皮質中に髄質が 混在し、未熟小型腎単位が索状に認められた。全体的に 尿細管上皮細胞のバルーニングがみられ、結合組織で取 り囲まれて重層化していて、内腔を埋めている像も多数 認められた（図13、図14）。

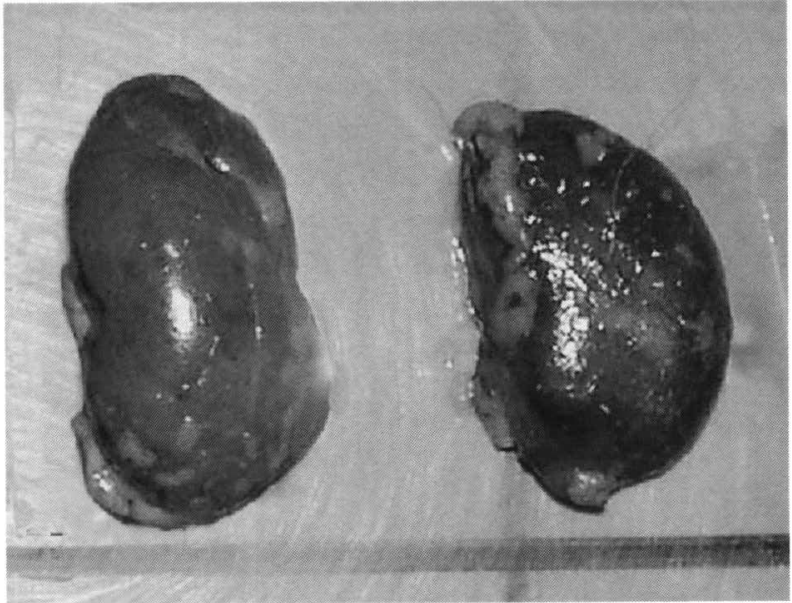

図12 左腎および右腎（症例 3 ）

左腎は大きさ $3.6 \times 1.7 \mathrm{~cm}$ 、重さ $7.8 \mathrm{~g}$ 、右腎は大きさ $3.2 \times$ $2.0 \mathrm{~cm}$ 、重さ $6.3 \mathrm{~g}$ で表面は退色し、分葉不明瞭であった。

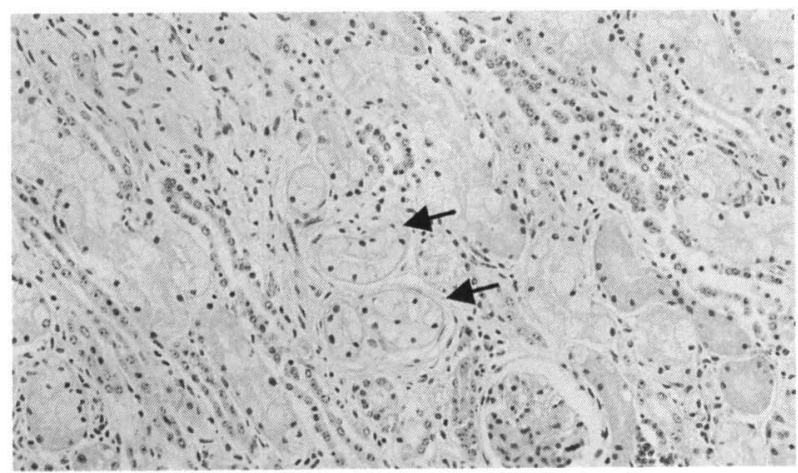

図13 症例 3 の腎臟（低倍）

矢印：尿細管上皮細胞のバルーニング 


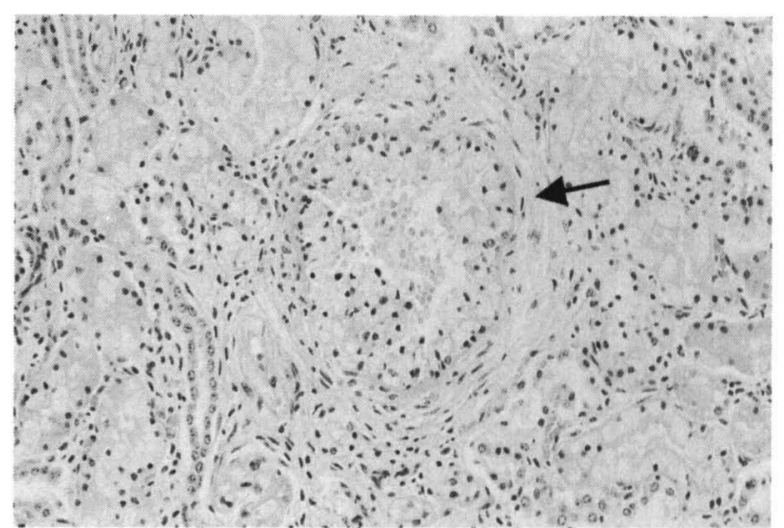

図14 症例 3 の腎臓（低倍）

矢印：尿細管上皮細胞のバルーニングがみられ、重層化 し内腔を埋めている。

\section{家系調査（図15）}

全症例において、茂金系種雄牛 $\mathrm{A}$ を頂点とする交配環 境であった。

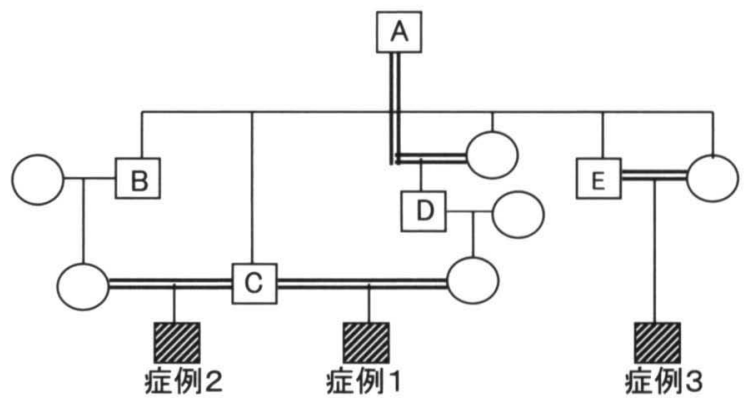

図15 血 統 図

$\square:$ 雄、O:雌、 $\square=0$ :近親婚をあらわしている。

\section{考 察}

今回の症例はいずれも低体重で出生し、臨床症状によ り子牛虚弱症候群と診断された。血液生化学検査や超音 波断層検査により腎機能異常が疑われ、解剖ならびに病 理組織学的検査によりそれが確認された。胎子における 腎臓の発生は、前腎が胎齢約10日齢頃から分化し始め、 系球体が形成されると尿の分泌が開始される〔1]。前 腎がまだ機能しているうちに、その後部には中腎が形成 され、胎生前期の泌尿器として重要な働きをする。後腎 は胎齢約18日齢で分化し始め、50日齢では最後部に位置 していた後腎は上方へ移動する。腎臓の形成異常を引き 起こす要因は突然変異や染色体異常の遺伝的因子と物理 的因子、科学的因子、食䭒性因子およびウイルス感染な どの環境的因子に大別されるが〔2〕、聞き取り調査に よりこれらの因子による可能性は低いと推察され、ウイ ルス感染については不明であった。

全症例に共通して種雄牛 $\mathrm{A}$ を頂点とした交配環境にあっ た。種雄牛 $\mathrm{A}$ は近親交配すると下顎短小および腎低形成 を発症することが知られており、本症例の腎臓形成異常 の要因として遺伝的因子による可能性が高いと推察された。
今回の症例のように下顎短小を伴わず、臨床的に子牛 虚弱症候群として診断された子牛に腎臓の形成異常が発 生していたことが明らかとなった。また、茂金系種雄牛 $\mathrm{A}$ の産子は他の種雄牛の産子より新生子虚弱による死亡 数が多く、母体内発育遅延が認められた割合も最も高かっ たという報告もある〔5]。種雄牛 $\mathrm{A}$ の近親交配による 産子の胎子死や子牛虚弱症候群の発生には、腎臓の形成 異常が関わっている可能性が推察された。

また症例 2 は、新生子期に子牛虚弱症候群と診断され、 治療により症状はある程度回復したものの、結果的には 発育不良となった。臨床症状や血液検査により腎機能異 常が疑われる場合に超音波断層検査を実施することは、 予後判定を含め、診断の一助になるものと考えられた。 今後、遺伝子検査等を行い発症原因を明らかにして、農 家の損失防止に努めていきたい。

\section{謝 辞}

稿を終えるに当たり、病理学的検索をご指導いただい た岩手大学農学部獣医学科御領政信助教授に厚く御礼申 し上げます。

\section{文 献}

1. 江口保暢（1995）. 動物発生学、131-135、文永堂、 東京.

2. 板倉智敏、後藤直彰編 (1994). 動物病理学総論、 230-233、文永堂、東京.

3. Kasari, T. R. (1989). Weakness in neonatal calves associated with dystocia. Agric. Practice. , $10: 19-25$

4. 小形芳美、高橋浩吉、阿部浩之、三澤 隆、漆山芳 郎、加藤敏英、酒井淳一 (1996)，黒毛和種における 虚弱子牛の血液性状および母牛との関係、日獣会誌. $50: 253-257$.

5 . 小形芳美、高橋浩吉、漆山芳郎、佐藤 光、酒井淳 一（1997）。黒毛和種における母体内発育遅延虚弱子 牛と血統との関連、日獣会誌. $50: 271-273$.

6. Ogata, Y., Nakao, T., Takahashi, K., Misaw a, T., Urushiyama, Y. andSakai, J. (1999). Intrauterine growth retardation as a cause of perinatal mortality in Japanese Black beef calves.

J. Vet. Med. A. ,46:327-334.

7. 高橋浩吉、小形芳美、酒井淳一 (1990). 和牛子牛 の死亡事故とその要因調査一虚弱子牛の血液学的なら びに病理学的所見を中心に一、家畜診療. 323:21-27. 